\title{
Denouncing your Own Sin: the Struggle for Subjectivity through the Publicization of Penance in Spanish Convents
}

\author{
Antoine Roullet \\ Fondation Thiers - CNRS. UMR 8596 Centre Roland Mousnier-Université Paris-Sorbonne-163 rue de Charonne 75011 Paris \\ e-mail: antoine roullet@hotmail.com \\ ORCID iD: http://orcid.org/0000-0003-0839-8888
}

Submitted: 5 April 2017. Accepted: 1 November 2017

\begin{abstract}
This article delves into the creation of subjectivity through the publicization of penance in Spanish convents. We seek to demonstrate that conventual sociability relied on the disclosure of each nun's interiority despite the discourse of self-denial the conventual institution was built upon. However, this presentation of the self was clearly restricted and had to fit within contradictory norms to deny and dispel any vain temptation to appear greater than the others. Nuns had to be humble, secret, moderate, strictly obedient, yet they were expected to edify one another, to be zealous and violent in their desire to mortify or castigate themselves. As introspection was a recommended activity, these double binds and the scruples they bred justify the systematic resort to tactics that relied on the leeway conventual life provided to work around the rule and seek recognition from the community. This necessary acknowledgment of each nun's flaws and deeds fostered a common interpretation of what was the most appropriate behavior inside the convent. Therefore, subjectivity was jointly built through these self-disclosing techniques and the reaction of the community.
\end{abstract}

KEYWORDS: Convents; Mortification; Subjectification; Dissimulation; Institution

Citation / Cómo citar este artículo: Roullet, Antoine (2017) "Denouncing your own sin: the struggle for subjectivity through the publicization of penance in Spanish convents". Culture \& History Digital Journal, 6 (2): e016. doi: http://dx. doi.org/10.3989/chdj.2017.016.

RESUMEN: Denunciar tu propio pecado: la lucha por la subjetividad a través de la exhibición pública de la penitencia en los conventos españoles.- Este ensayo profundiza en algunos modos de subjetivación en los conventos barrocos españoles. Se trata de describir como la institución conventual descansaba de manera indirecta sobre una revelación mínima de la intimidad de las monjas, pese al discurso de destrucción de la identidad personal llevado por los conventos. Esta presentación de sí mismo a los otros se apoyaba sobre el discurso despreciador vinculado a las obras penitenciales y era restringida ya que tenía que cumplir con normas contradictorias. Los dobles constreñimientos de la vida religiosa y la práctica de la oración mental y el uso de la introspección generaron muchos escrúpulos y explican el recurso generalizado a tácticas que aprovecharon todas las márgenes de maniobra para presentarse frente a los otros para buscar reconocimiento y a aliviar los temores que agitaban a las monjas a propósito de la salvación. Este proceso que implicaba a la comunidad en la fabricación del sujeto, también condicionaba la jerarquización social y el fortalecimiento de las relaciones interpersonales dentro de la sociedad conventual.

PALABRAS CLAVE: Conventos; Mortificación; Subjetivación; Disimulación; Institución

Copyright: (C) 2017 CSIC. This is an open-access article distributed under the terms of the Creative Commons Attribution License (CC BY) Spain 3.0. 
In early modern Europe a common stereotype concerning Spaniards was their taste for "vain exteriorities" (Guicciardini, 1953: 32). This cliché was reified throughout the sixteenth century when travellers disapproved of women's make-up and when religious authors insisted on the cult of appearances as a specifically Spanish vice Venegas, 2001: 271), as if "los españoles del siglo de oro [fueran] criaturas entregadas a la apariencia" (Rubio, 2016:46). Such conclusions regarding Spanish mentalities were particularly prominent when discussing religious practices (Platter, 2000: 495) $)^{1}$ and penitential processions which spread across the peninsula after the 1520's (Joly, 1909: 554). Much has been done to dispel such hasty judgments. Spain was officially built on the denial of religious plurality despite its internal fractures and frontiers (Stallaert, 1998; García-Arenal, 2016: 54). Therefore, the slow confessionalization of Castilian society throughout the sixteenth century, especially after the Council of Trent, heightened the need for individuals to publicly display their unquestionable affiliation to $\mathrm{Ca}-$ tholicism.

This black legend of Spanish people as both vain and fanatical relies on a symmetrical cliché of "Spanish interiority". Far from willing to essentialize "the Spanish", Unamuno lamented the long-standing consequences of National-Catholicism and insisted on the consequences of such an historic accounting of "national psychology". According to him, Spanish people tended to have a divided or dissociated soul (Unamuno, 1996: 99 sq.), violently torn apart. From the perspective of the outdated debate over the black legend and the failure of liberalism in Spain, Counter-Reformation mentalities and the culture of control in modern Spain had nourished a desire for subjection that prevented the emergence of an autonomous and self-conscious subject, contradicting the teleological tale of the victory of modern self-control over traditional obligations. Even though the assumption that there is indeed a "Spanish subjectivity" is rather dubious, the formation of subjectivity in early modern Spain has been a growing field of research, especially among specialists of early modern literature. The Journal of Interdisciplinary Literary Studies released a special volume on the topic in 1994. Building on Maravall's classical analysis of baroque culture as a culture of crisis (Maravall, 1975), discussions have shifted from the question of Spanish national specificities to that of the "crisis" in the formation of subjectivity in the baroque era (Cascardi, 1992; Mariscal, 1991; Rodríguez de la Flor, 2005; Spadaccini and Castillo, 1994, Butler, 2012). Even if many of these studies rely on literary and specific cases of which we can hardly generalize (Gracián, Quevedo, María de Zayas and so on), it became historiographical common ground that both the building of the modern State and the adjustments of aristocratic culture (Sánchez and Lewis, 1999) explain the contradictions of a "baroque" or "early modern" form of self-conscience, prone to secret and dissimulation, which extended far beyond just Spain. The processes of civilization, confesionalization, and social discipline that European societies allegedly experienced in the early modern period strongly shaped people's perceptions of themselves. They favoured reflexive work which is obvious in the proliferation of scruples or in the success achieved by asceticism and neo-stoicism among late $\mathrm{XVI}^{\text {th }}$ century elites, including in Spain (Carrasco Martínez, 2003). Subjectivity would have needed to reorder itself (Bouwsma, 2000: 165) to confront the tightening grasp of religious and royal political authorities on people's lives.

This article returns to this historiographic trend from a different perspective. Now that the teleological myth of the "birth of individualism" associated with the "Renaissance" is collapsing, we do not intend to return to the socalled emergence of subjectivity after Descartes (BedosRezak and Iogna-Prat, 2005; Boulnois, 2013; Taylor, 1989), but to shed light on forms of subjectification in late $\mathrm{XVI}^{\text {th }}$ century Spain. Utilizing this notion allows for a better analysis of the joint work of individuals and institutions in the process of becoming a subject (Butler, 1997: 2). We will focus on the exteriorization of penance inside feminine convents which was a neuralgic issue of the Spanish black legend. Conventual life was indeed a highly esteemed way of life in baroque Spain, the vigour of anti-monastic clichés being a measure of the prestige associated with the ideals they represented. Most importantly, convents were places where a "desire for subjection" was highlighted and defended as a path towards sanctity. It is commonplace to describe conventual life as a set of technologies destined to undermine personal identity and, in the long-run, subjectivity - the affirmation of an "I", gifted with a personal point of view, with the ability to choose and with a reflexive sense of ones difference from other selves - but whose agency is still dependent on a collective discourse s/he never chose. Indeed, the persecutory measures enacted in conventual life heighten this assessment: renunciation of your name, theoretical abolition of every visible distinction between each member of the community, personal and collective asceticism, strict obedience to the superiors, etc. The hagiographical commonplace of denying subjectivity has become popular in scholarship ever since the sociological tradition of total institutions assumed that jails, asylum and convents destabilize their residents' self-conscience (Goffman, 2007).

Yet, early modern convents did not comply with the ideals of monastic life. Accommodation with the rule was a necessity and the undermining of subjectivity, of which convents were theoretically built upon, was probably mislead. Still, focusing on these accommodations and discrepancies between norms and practices would miss the point. Our point is that convents did allow and stimulate specific forms of subjectification which served to strengthen authority inside the community. Monastic rules have not always been preoccupied by this war on subjectivity (Diem, 2015) and the authoritarian culture of control developed during the Counter-Reformation was far from an obstacle to self-control and reflexivity (Cascardi, 1992: 251). Since the 1990's, a vigorous historiographic trend has defended the idea that feminine con- 
vents were indeed spaces of (reasonable) liberty for women and could be described as places which stimulated the expression of feminine subjectivity and feminism (Quinsey, 2012), especially through mysticism but also through common reading and writing (Schlau and Arenal, 2006; Baranda Leturio and Carmen Piña, 2014; Cruz, 2004; Carrera-Marcén, 2005). Mental prayer, and requisite dialogue with the confessor to discern and discuss the always suspect graces nuns thought they received during prayer (Bilinkoff, 2005; Haliczer, 2002; Sánchez Lora, 1988), turned convents into paradoxical institutions, constantly uprooting any form of personal identity but still cultivating introspection.

Our purpose is to reject this double bind and study the conventual ways of expressing subjectivity at the heart of its destructive agenda, mortification. Spiritual autobiographies and hagiographical chronicles from the discalced Carmelite order form the basis of the research for this article. The nuns wrote these themselves, under the command of their superiors and confessors. Spiritual autobiographies were meant to help evaluate the nature of their visions and the quality of their contemplative skills, with the potential of pushing some of them forward on the path to sanctity. Hagiographical chronicles and lives were thought to offer models of sanctity to encourage newcomers and homogenize religious practices. They were mostly produced between the 1580 's and the 1630 's, right after the Reform of the Carmelite order, when it needed to write its own history and foster its own collective identity as its first generation was disappearing. Not only do these documents allow for a description of penitential practices but they also provide information on the reception of asceticism within these communities. This mostly unspoken dialogue, between each nun and her fellows, was crucial to the process of subjectification involved in the manifestation of personal sin. Even for nuns who tried to fit within conventual norms, mortifying techniques were supposed to disclose their intimate sentiments about themselves. Attention to the discrepancy between what nuns hoped to display and what was acknowledged by their superiors allows for a better understanding of the construction of subjectivity inside Spanish convents. This article demonstrates that the exteriorization of intimacy and the revindication of subjectivity were crucial to the conventual institution.

\section{FIGHTING FOR THE BOUNDARIES OF SUBJECTIVITY}

The conception of interiority that nuns were familiar with is central to the understanding of this process. "Subjectivity" obviously did not belong to the early modern Spanish lexicon, if only because the existence of a secured self and the existence of a reflexive conscience were not firmly recognized. Firstly, the boundaries of interiority were constantly endangered and had to be protected and fortified through a constant struggle against the believer's enemies: the devil, the flesh, the world. Secondly, this construction of interiority was a necessary step towards union with God, which was ultimately another dissolving moment for subjectivity. Still, spiritual life implemented several technologies of the self which stimulated reflexivity and implied an expansion of interiority, rooted in the use of mental prayer, in the necessity to remain silent (Gabriel, 2007), and in the habit of interpreting any event through the perspective of a providential plan in which every singular soul had a part to play. Moreover, regular confession and the increasing recourse to general confession, which spread in the Iberian Peninsula in the second half of the sixteenth century, had consequences for self-perception as it produced a sense of continuity of selfhood. As Mary Douglas noted in her classic work on self-knowledge, this unity and continuity is decisive in the occidental tradition whereas other civilisations rely on completely different notions of the self (Douglas, 1994: 218). Per this British anthropologist, this specificity should be ultimately related to a moral necessity, as everyone could and should be considered responsible for what they did. Indeed, we shall see that the perspective of judgment is critical to the formation of subjectivity within Spanish convents.

Yet this continuity and integrity of selfhood was never considered a given in the early modern era. It was always something you had to struggle to achieve. In early modern spiritual literature, interiority was constituted less as a location than as a space which had to be built. It was not immediately a quiet retreat from the world, but a mystical place expected to be unveiled and defended, however uncertain it might be. This conception of interiority as a secret place whose boundaries were unclear had much to do with sixteenth century religious anthropology, which was roughly Aristotelian, despite the variations from one author to another (Bergamo, 1994; Vidal, 2006; Roullet, 2015), including within the discalced Carmelite tradition (Roccetti, 1999; Cepeda-Adán, 1988; Alvira, 1992). Following the model of the De Anima, the Aristotelian tradition as it was interpreted in western Christianity distinguished between a vegetative, a sensitive, and an intellectual soul, all of which should not be understood as three separate parts of the soul but as three modalities of its interaction with materiality. The vegetative soul was supposed to be common to all living beings and responsible for their growth and generation. Sensitivity allowed animals to move and feel. Finally, angels and human beings, elected by God to rule Creation, were gifted with an intellectual soul with different powers (potencias) such as memory, willpower, and reason, many authors even claimed the existence of a spiritual soul, beneath the rational one which could be invested by God. The articulation of these three modalities of union between body and soul was a sensitive topic, for they were considered similar to the Holy Trinity (Venegas, 2001: 333; Soto, 1962: 108; Esbarroya, 1973: 276; Granada, 1996: 231) and the Incarnation of Christ (Roullet, 2013). Still, body and soul were supposed to be connected in the struggle for salvation (Baschet, 2000). A spirit guided by grace would hopefully sanctify the whole person, body and soul. The saint was considered entirely consistent with the image of 
God infused in his soul when he was created. On the contrary, this primordial image was blurred, disfigured, buried or tainted in the sinner's soul because he had yielded to temptation. The frailty and mobility of the relationships between body, world, and soul were dangerous and are the reason why religious life required patient work to control this fluidity and fortify interiority. Interiority was thought of as a battlefield that needed to be secured in the hopes of freeing the spirit from corporal and mundane influences, so that is could be, at last, invested by God.

This challenge was even more difficult considering the integrity of the person was never guaranteed. It has been argued that the emotional and physical violence staged in early modern theatre, especially in England, has to be considered as an indication that in the early modern era impulses which negated selfhood outstripped the forces that strengthened it (Marshall, 2002). Indeed, both the widely commented upon violence and rhetoric of passions, and the well-known porosity of selfhood in the sixteenth century, compounded this fragility of interiority. Since Cassirer, Renaissance anthropology has been described as a world of correspondence in which the body is less a frontier that an entry point for the whole macrocosms within the microcosms of the persona (Cassirer, 1927). Natural and unnatural forces always threatened to dissolve selfhood, especially with the renewal of medicine which seemed to increase the dominion of the body. In 1581, the Inquisition censured Huarte de San Juan because some sections of his Examen de ingenios para las ciencias (1575) relied on the Galenist tradition that seemed to contradict the immateriality of the soul. Some authors such as Alejo de Venegas developed the idea that humoral complexion constrained freewill to the point that each humour fostered specific sins. Obviously, sixteenth century spiritual writers mostly assumed this interdependence but tended to underline how harmful it could be to Christian salvation. Additionally, the dissemination and revival of late-medieval treatises on the discernment of spirits (Sluhovsky, 2007) was built upon the fear that interiority was not a sanctuary but could be invested by the devil. "Entrenched" (Venegas, 2001: 303) inside the body, shaking its humours and relying on its close interdependence with both the world and the soul, inspiring sinful movements, the devil always hoped the flesh would fail man. Therefore, intimate movements had to be scrutinized, filtered, and classified. Moreover, the idea periodically spread that judgment day was close and that demonic legions were slowly strengthening their grip on a crumbling world devastated by sin and heresy (Ángeles, 1998: 111). One of the ramifications of this panicked assumption was the belief that people were much weaker than they had been in the blessed time of Creation. Devils and demons are familiar characters in conventual chronicles, always trying to trick nuns into breaking their rule, screaming to break monastic silence, violently assaulting them. In the rhetoric of hagiographical chronicles, these demonic apparitions are mainly deceitful but in spiritual autobiographies they do reveal vehement anxieties regarding the lack of interior control nuns believed they ex- perienced when they were asked to write about themselves (Poutrin, 1995). One example illustrates this despondency. María de San Alberto confessed she saw devils playing with her own soul ("peloteaban con mi alma, como si acá unas personas se hicieran una rueda y tomaran una pelota y la fueran arrojando de mano a mano") clearly indicating that she no longer considered herself in control of her own salvation ${ }^{2}$. Eventually, anxiety would breed suicidal tendencies, pushing hagiographical rhetoric to its limits:

Apretóla nuestro Señor a tiempos por dos años con tantas dudas de las cosas interiores y otros trabajos que algunas veces se postraba en tierra y de la fuerza de la tribulación echaba sangre por boca y narices. Llego un día de S. Dionisio Areopagita y la apretó tanto junto con que se había de condenar y que supuesto esto mientras más viviese había de ser añadir pecados a pecados y materia de mayor condenación para eso mejor era acabar con la vida y aparecióle el demonio en figura horrible con una soga en la mano en el aire ${ }^{3}$.

If fears of damnation and lack of control were common in the early modern experience of reflexivity, mortification was one of the answers convents provided to these anxieties, especially for women since they were considered naturally weaker in the struggle against sin. The classical and (not only) Theresian image of the castle of the soul was not conceived as an egotist and ethereal representation of selfhood but as a demanding model to follow. Asceticism and glorified self-denial or self-annihilation were widespread themes in early modern hagiography and spiritual literature ${ }^{4}$. Self-hatred was commonplace in the ascetic tradition and a necessary step in the negative way to God (Gabriel, 2007). All personal desires were to be melted into God's will, reason should be guided by His light, which had been discerned in prayer, all movements of the flesh had to be tamed and treated as exterior impulses, even though they relied on a given and personal complexion. Mortification would breed a new man, a stranger to the nefarious influences from outside and whose interiority would be a pure instrument of God's will. Therefore, the purpose of interior and exterior mortification was to cut off interiority from any exterior impulses, as Luis de Granada used to say, backed up by a long medieval tradition:

Cierra la puerta de la celda de tu cuerpo, para no salir fuera de ella, y la puerta de la lengua, para no hablar, y la ventana interior de tu anima para no dar entrada a los espíritus sucios ${ }^{5}$

Once flesh and all its movements had been tamed, when the whip had flogged the skin until it was insensitive leather resistant to the devil's arrows (Granada, 1997: I, 148), when all senses were closed, when food no longer had taste, when perfumes and filth smelled the same, selfmortification had turned the body into an asset to fortify sanctity, into a firm frontier and a wall protecting interiority from any possible assaults from outside. Interiority lay 
in that movement and in the desire to reach God, either positively in the will to disappear in His own Will or negatively in repeated mortification and renunciation of the world and in the efforts to repel and exteriorize all nefarious influences. Since true rest was only thinkable in God and in the dream of a dissipation of any kind of subjectivity, since any interior movement was always thought to be guided by harmful exterior forces, resistance to temptation and self-denial were considered moments of truth. The urge to put their body and their willpower on trial was one of the rare experiences of subjectivity that were unquestionable because you felt in control. From that perspective, self-mortification was one of the sources, or at least one of the manifestations, of baroque perceptions of selfhood as a social monad hopelessly struggling against exterior powers (Maravall, 1975: 412).

\section{SELF-FASHIONING FOR THE OTHERS}

As primarily a means to personal salvation, self-mortification is often described as the solitary activity of a single person within their intimate relationship with God. Most chronicles insist on the personal use nuns made of hairshirts, cilices, and whips, on their continuous fasting, on the blood they shed in their cell. However, convents obviously organized and supervised penitential practices as a collective process. Regardless of all the implied difficulties, facing the others was considered crucial to accomplish a satisfactory penance. Self-control was realised through collective penance - self-flogging in the choir and through the strict and collective control of nuns' exteriors which was supposed to have positive consequences on their self-control. Firstly, the monastic habit was a stereotyped and visual set of the communitarian values every nun was supposed to represent. Secondly, self-fashioning techniques" (composición de sí mismo) embodied these values beyond the habit itself. This set of bodily techniques, attitudes, and postures aimed to align the whole body to this official and pious discourse. The ceremonial treatises that were written for the Carmelite order praised attitudes than can only be described as oxymoronic, such as "benign severity" or "cheerful modesty" (Ordinario, 1622: chap. XII). Composition required you to keep your head straight, to walk with dignity, "with a slow and grave pace", the neck and all the body remaining stiff and upright. Except when they were praying, nuns had to look downward and their eyes should not gaze with too much intensity or affection. Discreet laughs were allowed if the mouth remained closed. When speaking, their lips could not twist and their voice had to be low and soft, keeping her distance from any interlocutor, for she could indispose them with her breath. Composition is always underlined in hagiographical relations. Chronicles from Madrid describe the gravity of the composition and the "composed walk" of Francisca de Jesús ${ }^{6}$. A life of Josefa de San Felipe underlines "her great exterior composition", another praises the "perfect composition" of Eufrasia de Jesús in Cordoba. From that perspective, the ability to comply better than the others with a common but theoretical model was the sole way to distinguish oneself since conventual life relied on the denial of any form of singularity except self-denial. This composition of selfhood was more than a conventual form of "Renaissance self-fashioning" (Greenblatt, 1980). Even though it set some nuns apart from the others, it was meant to conceal any sign of personal identity or self-affirmation with an explicitly artificial image. Self-disclosure was a tightly constrained necessity, as we shall see later, and composition consciously drove back any desire to express any form of singularity. To intensify this policy, nuns were constantly asked to look at each other as if they were "images of God", regardless of each individual's own reputation. At last, composition of the self was a difficult path to follow, a constant reminder of the high virtuous standards each nun was supposed to attain. Any breach in this composition was theoretically assumed as a lack of control and manuals reminded that any slackening in that domain had to be severely admonished ${ }^{10}$. Even if this typically baroque stress on dissimulation could give way to a form of hypocrisy, it was presented predominantly as a sign of prudence and a preventative measure meant to protect each soul's intimacy. As this self-composition was propaedeutic to inner self-control, it was also considered paramount to salvation.

What could nuns possibly think about their counterparts' perfect composition? In spiritual literature, judgements about exteriorities and their relationship with interiority were organised by two symmetrical and tirelessly repeated commonplaces. On the one hand, there was a requisite solidarity between the two. As many physiognomonist treaties maintained for decades, exteriorities reflected interiority. Most devotional treatises which those nuns were familiar with insisted on the traditional relationship between grace and beauty (García de Enterría, 1990), as if darkness and ugliness of the soul were the true consequences of sin which eventually appeared on the sinner's face. As Diego de Estella said: "ninguna cosa te hace tan feo como los vicios o pecados en que vives"11 (Estella, 1597). Sinners were supposed to be ugly because they could not keep their inner blackness and disfiguration from coming to the surface. Sanctity had to be beautiful, because grace, which was working from inside the saint, showed up on his or her face. From that perspective, composition was betting that interiority would adjust with a perfectly composed exterior. The ideal nun's perfect composition could be a measure of her purity and serenity. On the other hand, some authors reminded their readers that the cowl does not always make the monk and that "no andan de un traje el cuerpo y el espíritu" one knew to what extent exteriorities were true to interiority and the suspicion that exteriority was nothing but a treacherous lie was widespread in Spanish society, especially since Jews and Moriscos were always accused of hiding their traditional beliefs. Behind convent walls, such an assessment had a different meaning. Feigned sanctity is not only one of the major topics of early modern historiography since the 1990's (Zarri, 1991; Giordano, 2007), it was also a concrete concern inside convents, 
since the condemnation of Magdalena de la Cruz in Cordoba (1546) and especially after the disaster of the false prophecies of María de la Visitación in Lisbon (1588) (Haliczer, 2002; Keitt, 2005: 55; Kagan, 1991: 124). Speculation about the discrepancy between the public image nuns had constructed within the community and the alleged purity of their soul were at the heart of conventual social life. Personal relationships among the community tended to stage the revelation of each nun's inner holiness and to protect their intimacy - hence the demand for perfect composition -, for any uncontrolled sign of sanctity could be described as ostentatious or vain and condemned as an effort to gain favour and power inside the convent. A perfectly mortified nun could always be suspected as her own idol and all her efforts would have meant nothing if she had turned her own achievement into an object of pride and into a new form of exteriority, insidiously deforming her soul and conforming herself with a treacherous image of sanctity. The opinion about what nuns displayed to others balanced between these two possibilities. In the 1620's, María de San José Lobo had difficulties with part of her Lisbon community because some nuns visibly perceived her penitential excesses and numerous licenses to complete additional acts of self-mortification as strategies to gain the favour of the male superiors of the order ${ }^{13}$.

Yet despite this cult of humility, sanctity had to be collectively recognised as a personal achievement, even though it was simultaneously presented as a gracious gift. Indeed, this exteriorization of their interiority was a necessity. Despite the risks of self-disclosure involved, nuns could never gladly accept the praises their perfect composition and obedience granted them. Even though they may be tempted to, their reputation was not sustainable in the long run if their perfect public image was not periodically confirmed and recognized as an expression of their interiority. The never ending gap between what a nun displayed and what she pretended to be is crucial to understand how winding and tortuous the collective building of sanctity could be. It was necessary to maintain a distance and a discrepancy between what people considered a public reputation and what was presented as an expression of subjectivity. This tension between public reputation and self-assertion had to be put on trial and nuns needed to demonstrate their sincerity and expose themselves. If truth-telling is obviously crucial in the Christian tradition (Foucault, 2012), it was not easy to stage in Spanish baroque convents.

\section{STAGING SUBJECTIVITY IN SPITE OF UNIFORMITY}

These tensions resulted from the double binds (Sluzki and Verón, 1971) conventual life was built upon: being a saint in the realm of uniformity, being an elite yet remaining humble, being zealous yet remaining discrete, violent but always in control, etc. These contradictory demands deeply constrained any expression of subjectivity and personal prowess. Rather than long-term and planned strategies, nuns implemented day-to-day tactics of secondary adjustments (Certeau, 1990: 59; Goffmann, 2007: $55)$ to disclose their opinion about themselves. All these tactics relied on the manifestation of their supposedly corrupted and wretched soul since, paradoxically, the most secure self-fashioning technique of sanctification was to claim to be a sinner. The best opportunity to make any weakness public lay in the obligation to disclose these to superiors in the hope they would be corrected. The exteriorization of personal sin is obvious when nuns constantly complained about themselves, when they repeatedly returned to confession, or when they insisted on asking for licenses to do additional acts of penance, a traditional prerogative of the prior emphasized in the Carmelite Constitutions (Álvarez, 1995). By doing so, nuns were demonstrating that they had personally interiorized the collective eschatological anxieties which haunted early modern Europe. They were shaped by these collective fears yet at the same time they were perpetuating them among their sisters through their own, personal and incarnated devilish stories. Even though these petitions and manoeuvres theoretically remained secret, news of these eventually spread inside the community and show up in hagiographical relations. These sources always present the exteriorization and maximization of sin ("la más pecadora del mundo"14 "la más ruin y flaca de cuantas criaturas dios a criado"15) as paradoxical proof of ingenuity and humility, maintaining a difference between self-perception and a hypothetical "true" state of the soul. In Beas, Francisca de San José claimed that she constantly feared for her own salvation because she was the worst possible sinner, but her confessor ultimately confirmed that he found no sin, besides scruples, in her tortured soul when she confessed before her death in $1656^{16}$. Historians can obviously only speculate on any of these nuns' intimate sentiments about themselves. Whether these nuns were devout women sincerely convinced of their own depravation, were assuming a rhetoric of femininity and humility to convince their male superiors (Weber, 1990; Mújica, 2004), or were mischievous and Machiavellian subjects consciously manipulating their counterparts is beyond our reach. Besides, the answer to that question was willingly transferred to the community. This discourse of self-hatred and self-annihilation relied on the affirmation of a reflexive singularity, willingly giving herself to the authority and judgment of the others, but claiming to be a sinner in the few discussions she was supposed to have with her superiors within her day-today unspoken routine. From that perspective, it can be described as a political subjectification in the sense that this rhetoric enabled "individuals to be described (by others) and identified (by themselves) in the public arena" (Fassin, 2008: 533).

Yet, speaking with superiors or with trusted sisters was not the best nor only way to express self-hatred since it threatened the vow to remain silent. The resort to bodily mortification should be understood as a more discrete disclosure, even if it was also very constrained. In theory, self-flogging, hair shirts, or metallic cilices did exteriorise 
personal sin. Their traditional function as exomolegesis (Foucault, 2012: 190-210) in the high middle ages was to show and express the true state of the sinner's soul. Penance depended on an extirpating violence (Crouzet, 1990: 245) which harkened back to this tradition and aspired to uproot sin and reveal it. For most nuns, and especially for those whose reputation was not firmly established among the community, the demonstration of personal sin through penance was risky, and not only for reasons of modesty, decency, or humility. There were official and regular moments of collective penance, several times a week, and they could be asked to keep to that collective duty. However, only personal mortification could be understood as an individual and subjective action presented to the community and humbly manifesting the anxieties of a given individual preoccupied by her own salvation. Therefore, conventual chronicles always described self-flogging as a dissimulated practice, betrayed by the sound of the whip on flesh, by the paleness of a face, by old scars unveiled when nuns rolled up their sleeves to wash the ground. In a 1636 chronicle, Juliana de la Madre de Dios is praised significantly for the way she tried to cover up the blood splashes on her cell's wall:

Tenía siempre salpicadas de ella las paredes de su celda y aunque las raía muchas veces por disimular por sus hermanas quedaran con todo eso muchas partes teñidas con sangre ${ }^{17}$

Other nuns managed to maintain this requisite balance between disclosure and discretion. When an inquiry was made in 1627 Lisbon about the life of Maria de San José Lobo, including a methodical interrogation of every living nun, some members of the community praised her discretion when she flogged herself at night in a remote part of the convent or when she altered her Friday meals with unknown bitter substances ${ }^{18}$. Others were unaware of it or decided not to disclose that information. This demand for secrecy must be taken seriously. Conventual chronicles always implied that penance was unintentionally disclosed or that nuns failed in their efforts to hide themselves. In hagiographical terms, self-disclosure was one further step toward mortification. We can obviously never know if their desire was to be discovered, but the point is that conventual life constrained the way their subjectivity could be staged and organized its betrayal, notably though the promiscuity of everyday life, especially in the first years of each community, when reputations were made and when proper conventual buildings usually did not exist. Besides, if necessary, God would help to disclose a saintly reputation and outstrip any effort made to keep it secret. This was a commonplace when it came to the exteriorization of spiritual graces and ecstasy ${ }^{19}$. In spiritual autobiographies, mystical ecstasies were not presented as a reward for perfection but as a gift which could not be declined. Mysticism, even though it could undoubtedly be recognised as a proof of sanctity among the community, did not openly counter the self-depreciating speeches nuns were meant to make about themselves.

\section{DISPLAYING SUBJECTIVITY THROUGH PENANCE}

However, this stress on secrecy which is prominent in nun's accounts and hagiographies should probably not be overestimated. The routinization of regular life and the fact that something of every nuns' intimacy was disclosed diluted these requirements. Besides, there were more explicit ways to express penitential desires, such as castigating the few body parts that were not hidden behind the habit. Some nuns carried out penitential exercises that focused on their face and their hands. A nun from the convent of Cuenca, Mariana de San Angelo had the strange habit of tearing her eyelashes off in an effort to "deface herself", according to the chronicle of the convent ${ }^{20}$. A Portuguese pupil of John of the Cross from the convent of Segovia also used to rip her eyelashes off, and bring poultry droppings into her cell ${ }^{21}$. We can assume she took them with her bare hands as Francisca de Jesús used to do. This founder of the Descalzas Reales of the order of saint Clare in Madrid claimed that she often washed the convent dustbin with her bare hands, to the point that it was impossible for her to get rid of the filth ${ }^{22}$. Petronila de la Encarnación used to plunge her face in the spittoon the nuns had placed at the entrance of the choir, Brianda de San José did likewise in a sick nun's basin ${ }^{23}$. Ana de Palma, a nun from Toledo who took care of the convent's garbage, enjoyed keeping her delicate hands polluted by the kitchen water $^{24}$. Paciencia de San Lorenzo once washed her hands in a bowl containing a sick nun's vomit (Bautista de Lanuza, 1659: 106). The founding mother of the convent of Beas used to clean her face with the poultry's water to blacken her complexion ${ }^{25}$. By doing so these nuns perhaps reinterpreted traditional gestures of public mortification, such as the habit of covering your face in ashes, an Old Testament tradition that was commonly reactivated in Spanish convents. They also explicitly taunted the official canons of beauty of the early modern age, as they focused on their hands and white faces. Such practices, although not exceptional were uncommon, no doubt because they were too explicit. These can be interpreted as a response to the mundane culture of make-up and perfume that was spreading among the Spanish elite. Indeed, these practices were usually associated with nuns coming from the upper circles of society, and are probably a sign that it was easier for them to play on the margins of conventual norms. Still, there is no doubt that nuns were careful with this discrepancy between exterior and inner beauty. The founder of the reformed Carmelite order, Teresa of Avila, explicitly referred to such a contradiction in a discussion with her niece Beatriz de Ovalle. The purpose was to warn her against her obvious physical beauty: "No pensáis por esos que sois hermosa que negros ay que se le parecen a blan$\cos ^{226}$. Underlying this play on beauty and social status, such practices of defacement relied on the devotional commonplace of the ugliness of sin and were a speechless and public act of self-assertion. Still, they remain ambiguous, especially the blackening of complexion. Teresa's 
observation is probably an allusion to the following verse of the Song of Songs, a familiar text for every nun and especially for her since she wrote a comment on it: "Nigra sum, sed formosa, filiæ Jerusalem, sicut tabernacula Cedar, sicut pelles Salomonis"27. A classical exegesis of this verse which goes back at least to Saint Bernard and was supported by most Spanish exegetes of the time (Cipriano de la Huerga, Luis de León, Arias Montano) ponders that "debajo dese color moreno esta gran belleza" (León, 2003: 112; Arias Montano, 1990: 20). From that perspective, ugly faces and ripped clothes no longer indicated a wretched and uncontrolled soul but were considered a prophylactic and humiliating image meant to hide interiority. In other words, self-defacement was a way to voice and reveal a so-called truth of the soul and it managed to accommodate this self-denying speech with the idea it could indeed cover-up the great treasure of a perfectly humble soul. Both the sincerity of the penitent nun and the necessary difference between what was revealed and what was perceived of interiority remained safe.

Finally, monastic tradition did provide situations in which the constraint on the exteriorization of sin could be lightened, for public punishments in the chapter room or in the refectory were considered edifying shows. Chronicles always praise nuns wearing wooden crosses, kissing the feet of other members of their community, eating stale bread on the ground, standing with their arms spread-eagled or laid in the entrance of the room in the hope of being stepped on $^{28}$. These public acts of humiliation were usually performed by the prioress or by prominent members of the community, on specific occasions - specifically Good Friday - to illustrate how experienced nuns excelled at self-denial exercises. Teresa of Avila was praised for walking on all fours on the ground of the refectory, carrying rubble on her back, and being guided by a younger nun as if she were a mare ${ }^{29}$. This impressive yet classic practice ("hacer el borriquito" ${ }^{30}$ ) no doubt strengthened her reputation especially since she was already a recognized madre and such an exercise was probably no longer necessary to assert herself. Still, performing mortifying acts in front of others was one of the best ways to build a reputation and affirm your authority inside the convent, provided you were no longer suspected of being driven by vanity or careerism. Anyone could ask for a license to perform public mortification in front of the whole community and such customs were also considered edifying practices for the novices. Indeed, for those plagued by scruples and fear for their salvation, public punishment may have been a way to embrace penance without fear of the judgments of others. It was hopefully a reassuring moment of coincidence between what they displayed and what was perceived. Moreover, the cathartic and theatrical dimension of these performances should not be undervalued. Sin was considered a distortion and defacement of interiority for it blurred the image of God which had been stamped or printed in the deepest folds of the soul when it was created. In acting like an animal, in wearing hair shirts, in blackening their complexion, in revealing their inner ugliness, penitent nuns were not only disclosing the false images they had been following, they were casting them out and washing away their sin, liberating their interior from these chains. This transition via public penance is crucial to understand how the satisfaction of this desire for punishment, which is so common in conventual hagiography, loosened their anxiety because the community and especially the superiors took over the responsibility for their salvation. Comments on their performances were probably common. While in Cuerva, Isabel de San Alberto knelt in a pathetic show, stripped of her religious cloth and wearing a gross tunic, her hands crossed on her shoulders and triggered compassion among the community. The chronicle significantly insists on her angelic beauty in that moment, especially because she blushed with shame ${ }^{31}$.

Both this passion for punishment and subjection and the hope that your humility would be acknowledged encouraged many nuns to take advantage of the leeway provided by conventual life to publicize their humiliation and accept the judgment their peers would make. From that perspective, subjection to the authority of the prior should not be considered as yet another proof of the depersonalizing and self-destructive tendencies of religious life, but as a necessary means to balance and articulate the incorporation of often contradictory norms, the integration within the community and the protection of the souls which required guidance. Both the constitutions and the few instructions to the mistresses of novices we have (San José, 1978; San Bartolomé, 1998: 594ff) (Manero Sorolla, 1991) insist on the necessity of preventing any dissimulation and encouraging the novices to speak freely about themselves to their superiors, for incomplete disclosure was known as the devil's trap. In return, these superiors should be prudent and discrete and take care to discern and evaluate what was fit for each nun they supervised. For that same reason, confessors were required to be discrete in their discernment of each soul and superiors were often credited with the extraordinary gift of reading souls and always knowing what they could hide ${ }^{32}$. This shift from strict protective enclosure to complete disclosure restricted to the confessor and the superiors was one of the best solutions to strengthening the hierarchical and authoritarian function convents were built upon. Submission to the personal and discrete authority of the superiors was a negotiation, a discussion, and a discernment of what was considered the right behaviour in each community for each individual nun, favouring the adjustment between personal demands and the uniformity of common life. It was also a channel between each nun and the whole convent which would adjust its own judgment with the superiors' opinion. In the long-run, it shaped every reputation within the community.

\section{CONCLUSION}

Authority, life in common, and the dialectics of selfdenial and self-disclosure were deeply entangled because they were crucial to the functioning of convents as institutions. On the one hand, the terrifying discourses on the 
dangers that threatened the Christian soul, the propagation of sin, and the resort to penance were necessary to strengthen personal ties within the convent because they forced nuns to entrust one another with their own salvation. The proliferation of scruples and the fear of damnation encouraged nuns to disclose their anxiety, as hiding them was considered a temptation which could be fatal. Besides, conventual life was regulated by a set of complex and often contradictory injunctions (rule, constitutions, hagiographic models, obedience to the superiors, zeal and moderation, discretion and emulation, etc.) that could only encourage these revelations, even though the exteriorization of self was very constrained. Social relationships within the community were constantly adjusting to these contradictions. The necessary negotiation of what was considered right behaviour shaped social relationships within each community and contributed to the establishment of each nun's reputation. This common interpretation of the rule also legitimized the pre-eminence of experienced nuns and the power given to superiors both inside and outside the convent. Therefore, the respect of impersonal and collective rules did not directly guarantee the stability of conventual life but fashioned personal relationships of authority and fidelity that were crucial to conventual stability, in this case between every nun, especially the younger ones, and their superiors. In the final analysis, the strong and personal ties maintained within the conventual community relied on a constrained and very restricted subjectification of these personal anxieties, whose acknowledgment was paradoxically a sign of sanctity.

On the other hand, this building of sanctity through the expression of sin also legitimized the convent as a prominent institution in early modern societies. The idea that sin and heresy were proliferating, and the exigency of purification this implied, endorsed the idea that the order and fate of the Hispanic monarchy hinged on respect for a natural and divine order. This classic naturalization and divinization of social order legitimized every institution in the early modern era. Convents sustained familial strategies and honour by welcoming women who could not or would not be married and conventual prayers and penance were addressed to the salvation of the realm, the king, the local community, and the growing number of individuals who founded chapels and masses. In both cases, the efficiency of the institution relied on the idea that nuns were the closest persons to perfection and for that reason they had God's ear. As we've seen, these collective representations weighed on the processes of subjectification of these nuns and were in the meantime constantly reactivated, maintained, and reinforced by what these women revealed of their own experience. This joint formation of subjectivity is typical of how institutions perpetuate themselves through the shaping of each individual's agency (Douglas, 1986). From that perspective, the expression of subjectivity and the exteriorization of mortification inside Spanish convents, no matter how constrained they were, should not be considered as simply tactics of individual resistance to the depersonalizing forces of total institutions but as a critical necessity these institutions were built upon, for this process of subjectification wove threads that articulated self-expression all the way to the very foundations of society.

\section{NOTES}

1 Obviously, the fact that Platter was a Calvinist has a lot to do with his denunciation of Spanish religious ceremonies.

2 Fragmentos autobiográficos de la Madre María de San Alberto, Archivo Silveriano (Burgos), mss. 3A, p. 72: "they were playing with my soul, as if several people had gathered and sat in a circle to toss a ball from hands to hands"

3 Vida de la Madre María de Jesús, BNE, mss. 8693, f¹42r-“"Our lord did press her for two years with such doubts about inner matters among other trials que she sometimes prostrated herself on the ground and shed blood from her nose and mouth. One time on the day of S. Dionisio Areopagita, he tormented her so much with the idea that she was doomed and that, while she was living, she was only adding one sin after the other, fostering her own damnation, that it felt like the best solution was to end with her life. In that moment, the devil appeared in the air with a dreadful face, holding a rope in his hand."

4 For instance the very diffused Luis de Granada (1554: 154).

5 "Closet the gate of your body's cell, for you could get out, the gate of your tongue, to remain silent, and the inner gate of your soul so that filthy spirits won't come in" (Granada, 1596: 208).

6 Libro de la vida y muerte de las santas madres fundadoras del monasterio de las descalzas de la Villa de Madrid de la premiera regla de la madre santa Clara y de las que en el ha muerrto hasta asta oy 4 de diciembre 1595, BNE, mss 7712, fo 9r.

7 Antonio de San Joaquin, Vida de Josefa de san Felipe, carmelita de malagon (1739), BNE, mss. 13426, p. 40.

8 María de San Pablo, Noticias sobre algunas religiosas, BNE, $5807, \mathrm{f}^{\circ}$ 200r.

9 This is a commonplace. See for instance Feliciana de San José (1654).

10 Ordinario o ceremonial de las religiosas descalzas carmelitas conforme a las costumbres antiguas de su religion, Alcalà de Henares, Viuda de Juan García, 1622, cap. XII.

11 "Nothing makes you uglier than the sins and vices in which you live" (Estella, 1597: fo 54r)

12 "That body and spirit do not always follow one another" (Ángeles, 1998; 63-64).

13 María de San José (Sousa), Mercedes y favores que Dios hizo a la Madre María de San José, sacados de lo que dejó escrito de su mano, BNE, mss. 2711, fo 24r.

14 Relación de la vida de Madre Juliana de la Madre de Dios, Archivo Silveriano (Burgos), mss. 31H, p. 34.

15 Teresa de Jesús María, Autobiografia y relación de las mercedes divinas recibidas, BNE, mss. $8482, \mathrm{f}^{0} 62 \mathrm{r}$.

16 Datos sobre algunas madres de Beas, Archivo Silveriano (Burgos), mss. $16 \mathrm{H}^{-1}{ }^{\circ}$, s.f.

17 Vida de la Madre Juliana de la Madre de Dios, BNE, mss. 5807, fo 59r. "There were drops of blood on her cell's wall which she often tried to erase to hide them from her sisters. Still, some parts of it remained tainted with blood". See also Vida de la Madre Catalina de Jesús, BNE, mss. 5807, fo 381r; Isabel de San José, Fundación deste convento de San Josef de las carmelitas descalças desta ciudad de Cuenca, BNE, mss. 7018, fo 143r; (Bautista de Lanuza, 1657: 12)..

18 Informaciones sobre algunos religiosos y algunas carmelitas, BNE, mss. 2711, fo 143r.

19 See for instance Teresa de Jesús (1997: 109).

20 Isabel de San José, Fundación deste convento de carmelitas descalças desta ciudad de Cuenca, mss. 7018, $\mathrm{f}^{\circ}$ 142r.

21 Libro de profesiones de Segovia, ASB, 84T, p. 29.

22 Libro de la vida y muerte de las santas madres fundadoras del monasterio de las descalzas de la Villa de Madrid de la primera regla de la madre santa Clara y de las que en él han muerto hasta hoy 4 de diciembre 1595, BNE, mss. BNE, fo 8v. 
23 See also Informaciones sobre algunos religiosos y algunas carmelitas, BNE, mss. 2711, fo 141r. Informaciones sobre los religiosos y religiosas carmelitas descalzos del reyno de Portugal, BNE, mss. 2711, fo 42v.

24 De la fundación del monasterio de la Encarnación de las monjas descalçascarmelitas de la Villa de Cuerba, BNE, mms. 7018, fo $92 \mathrm{r}$.

25 Informaciones sobre Catalina de Jesús, fo 161r, testimony of Isabela de los Ángeles. Also see fo 149r.

26 Relación de la Vida de la Madre Beatriz de Jesús, BNE, mss. 8693, fo 460r.

27 Ct 1, 4. "I am black but beautiful, O ye daughters of Jerusalem, as the tents of Cedar, as the curtains of Solomon".

28 Manuela de la Madre de Dios, Vida de la Madre Leonor María del Santísimo Sacramento, BNE, mss. 7018, fo 63r; Nicolás de San Cirilo, Vida de las Venerables María de Jesús e Isabel de Jesús, religiosas de Beas, BNE, mss. 7737, fo 488r; Santas costumbres del monasterio de la Concepción del carmel de Valladolid, ASB, mss 57/D, p. 9; (Bautista de Lanuza, 1654: 103).

29 Relación de algunas virtudes particulares de las monjas de Toledo, BNE, mss. 7018, fo 222r; (Santa María, 1644-1655: I, 184).

30 Santas costumbres del monasterio del Carmen descalzo de Segovia, fo 8r. See also Costumbres santas de Ávila, Archivo Silveriano (Burgos), mss. 82A, p. 6; Brianda de San José, Fundación, prioras, novicias y difuntas de Malagón, BNE, mss. 7018, fo 425r.; (Bautista de Lanuza, 1659: 103).

31 Manuela de la Madre de Dios, Vida de la hermana Isabel de San Alberto, BNE, mss. 7018, fo $112 \mathrm{v}$.

32 Andrés de Cristo, Vida de Ana de San Agustín, Biblioteca Universitaria de Barcelona, mss. 515, fo 177r, De la Madre Isabel de Jesús, la ciega maestra de novicias, BNE, mss 3537, f 0 392r, Informaciones sobre Catalina de Jesús, BNE, mss. 5807, fo $155 \mathrm{v}$, Fundación y religiosas del convento de Consuegra, BNE, mss. 7018, fo 203v, Declaraciones sobre la Madre María de Jesús, BNE, mss. 8693, f $194 \mathrm{v}$. Leonor de la Misericordia, Relación de la vida de la venerable Madre Catalina de Cristo, BNE, mss 6621, fo $28 \mathrm{r}$.

\section{REFERENCES}

Álvarez, Tomás (1995) Constituciones de las Carmelitas descalzas. Teresianum, Roma.

Alvira, María Isabel (1992) Vision de l'homme selon sainte Thérèse d'Avila, une philosophie de l'héroüsme. FX de Guibert, Paris.

Ángeles, Juan de los (1998) Conquista del reino de Dios (1587). Edited by Martín, T.H. Biblioteca de Autores Cristianos, Madrid.

Arias Montano, Benito (1990) Paráfrasis del Cantar de los Cantares de Salomón en tono pastoril. Diputación Provincial, Huelva.

Baranda Leturio, Nieves and Marín Piña, Carmen (editors) (2014) Letras en la celda. Cultura escrita de los conventos femeninos en la España moderna. UNED-Iberoamericana Vervuert, Madrid.

Baschet, Jérôme (2000) "Âme et corps dans l'Occident médiéval : une dualité dynamique, entre pluralité et dualisme". Archives de sciences sociales des religions, 112: 5-30.

Bautista de Lanuza, Miguel (1654) Vida de la venerable Madre Feliciana de San Joseph, carmelita descalça y priora del convento de S. Joseph de Zaragoza. D. La Puyada, Saragosse.

Bautista de Lanuza, Miguel (1657) Virtudes de la V. M. Teresa de Jesús, carmelita descalza del convento de Valladolid. J. Lanaja y Lamarca, Saragosse.

Bautista de Lanuza, Miguel (1659) Fundacion y excelencias del Conuento de S. Ioseph de Carmelitas descalzas de Çaragoça. Pedro Lanaja y Lamarca, Saragosse.

Bedos-Rezak, Brigitte Miriam and Iogna-Prat, Dominique (editors) (2005) L'individu au Moyen Âge. Individuation et individualisation avant la modernité. Aubier, Paris.

Bergamo, Mino (1994) L'anatomie de l'âme: de François de Sales à Fénelon. J. Millon, Grenoble.

Bilinkoff, Jodi (2005) Related Lives: Confessors and their Female Penitents, 1450-1750. Cornell University Press, Ithaca.
Boulnois, Olivier (editor) (2007) Généalogies du sujet. De saint Anselme à Malebranche. Vrin, Paris.

Bouwsma, William J. (2000) The Waning of the Renaissance, 15501640. Yale University Press, New Haven.

Butler, Judith (1997) The Psychic Life of Power. Theories in Subjection. Stanford University Press, Stanford.

Butler, Justin (2012) "Baroque Subjectivity and the Modern Fractured Self”. (Re)reading Gracián in a Self-Made World. Hispanic Issues On Line Debates, 4: 6-28.

Carrasco Martínez, Adolfo (2003) "El estoicismo, una ética para la aristocracia del Barroco". In Calderón de la Barca y la España del Barroco, edited by Alcalá Zamora, J. and Belenguer, E. Centro de Estudios Constitucionales, Madrid: 305-330.

Carrera-Marcén, Elena (2005) Teresa of Ávila's Autobiography: Authority, Power and the Self in Mid-Sixteenth-Century Spain. Legenda, London.

Cascardi, Anthony (1992) "The Subject of Control". In Culture and Control in Counter-Reformation Spain, edited by Cruz, A.J. and Perry, M.E. University of Minnesota Press. Minneapolis.

Cassirer, Ernest (1991) Individu et cosmos dans la philosophie de la Renaissance (1927). Minuit, Paris.

Cepeda-Adán, José (1988) Antropología de San Juan de la Cruz. Institución Gran Duque de Alba, Centro Internacional O.C.D. de Estudios Teresiano-Sanjuanistas, Ávila.

Certeau, Michel de (1990) L'invention du quotidien. 1. arts de faire (1980). Gallimard, Paris.

Crouzet, Denis (1990) Les guerriers de Dieu. La violence au temps des troubles de religion, vers 1525 - vers 1610. Champ Vallon, Paris.

Cruz, Anne J. (2004) "Willing desire: Luisa de Carvajal y Mendoza and Female Subjectivity". In Power and Gender in Renaissance Spain, edited by Nader, H. University of Illinois Press, Chicago: 177-193.

Diem, Albrecht (2015) «L'espace, la grâce et la discipline dans les règles monastiques du haut Moyen Âge». In Enfermements II: Règles et dérèglements en milieu clos (VIe-XIXe siècle), edited by Heullant-Donat, I.; Claustre, J.; Lusset, É. and Bretschneider, F. PUF, Paris : 215-238.

Douglas, Mary (1986) How Institutions Think. Syracuse University Press, Syracuse.

Douglas, Mary (1994) Risk and Blame, Essays in Cultural theory. Routledge, London-New York.

Esbarroya, Agustín de (1973) Purificador de la conciencia (1550). Universidad Pontifica de Salamanca and Fundación Universitaria Española, Madrid.

Estella, Diego de (1597) Primera parte del libro de la vanidad del mundo. Juan Gracián, Alcalá de Henares.

Fassin, Didier (2008) "The Humanitarian Politics of Testimony. Subjectification through Trauma in the Israeli-Palestinian Conflict." Cultural Anthropology, 23, 3 : 531-558.

Foucault, Michel (2012) Du gouvernement des vivants. Cours au collège de France, 1979-1980. EHESS, Paris.

Gabriel, Frédéric (2007) “Contemplation, anéantissement, récit. Les stratégies du sujet spirituel à l'âge moderne". Cahiers de philosophie politique et juridique de l'université de Caen. Dire le néant, 43: 179-209.

García-Arenal, Mercedes (2016) "De la duda a la incredulidad en la España moderna: algunas propuestas". In Identidades y fronteras culturales en el mundo ibérico en la Edad Moderna, edited by Betrán, J. L.; Hernández, B. and Moreno, D. Universitat Autònoma de Barcelona, Barcelona: 51-67.

García de Enterría, María Cruz (1990) "El cuerpo entre predicadores y copleros". In Le Corps dans la société espagnole des XVI et XVIlème, actes du colloque international, Sorbonne, 5-8 octobre 1988, edited by Redondo, A. Publications de la Sorbonne, Paris: 233-244.

Giordano, Maria Laura (2007) "Al borde del abismo: faslas santas e ilusas madrileñas en la vigilia de 1640". Historia social, 57 : 75-97.

Goffman, Erving (2007) Asylums: Essays on the social situation and mental patients and other inmates (1961). Transaction Publishers, New Brunswick-London. 
Granada, Luis de (1554) Libro de la oración y meditación. Andrea Portonariis, Salamanca.

Granada, Luis de (1596) Libro de san Ivan Climaco llamado escala espiritual. Juan Gracián, Alcalá de Henares.

Granada, Luis de (1996) Quarta parte del Símbolo de la Fe. Fundación Universitaria Española, Madrid.

Granada, Luis de (1997) Primer guía de peccadores. In Obras castellanas completas. Turner, Madrid.

Greenblatt, Stephen (1980) Renaissance Self-Fashioning. From More to Shakespeare. The University of Chicago Press, Chicago-London.

Guicciardini, Francesco (1953) "Relazione di Spagna". In Opere, edited by Caprariis, Vittorio de. Riccardo Ricciardi, Milan-Naples: 27-47.

Haliczer, Stephen (2002) Between Exaltation and Infamy, Female Mystics in the Golden Age of Spain. Oxford University Press, New York.

Joly, Barthélémy (1909) "Voyage en Espagne de Barthélémy Joly (1603-1604)". Revue Hispanique, 20: 459-618.

Kagan, Richard (1991) "Politics, Prophecy and the Inquisition in Late Sixteenth Century Spain. In Cultural Encounters: the Impact of the Inquisition in Spain and the New World, edited by Perry, M.E. and Cruz, A.J. University of California Press, Berkeley.

Keitt, Andrew (2005) Inventing the Sacred. Imposture, Inquisition and the Boundaries of the Supernatural in Golden Age Spain. Brill, Leiden and Boston.

Manero Sorolla, María del Pilar (1991) "Un diálogo de carmelitas primitivo traducido al francés: Pour l'instruction des novices de María de San José. In Traducción y adaptación cultural: España-Francia, edited by Donaire, M.L. and Lafarga, F. Universidad de Oviedo, Paris.

León, Luis de (2003) El cantar de los cantares de Salomón, edited by Becerra Hiraldo, J.M. Cátedra, Madrid.

Maravall, José Antonio (1975) La Cultura del barroco. Análisis de una estructura histórica. Ariel, Barcelona.

Mariscal, George (1991) Contradictory Subjects: Quevedo, Cervantes and Seventeenth Century Culture. Cornell University Press, Ithaca and London.

Marshall, Cynthia (2002) The Shattering of the Self: Violence, Subjectivity and Early Modern Texts. John Hopkins University Press, Baltimore and London.

Mújica, Bárbara (2004) Women Writers of Early Modern Spain: Sophia's Daughters. Yale University Press, New Haven.

Ordinario o ceremonial de las religiosas descalzas carmelitas conforme a las costumbres antiguas de su religion (1622). Viuda de Juan García, Alcalá de Henares

Platter, Thomas (2000) Le voyage de Thomas Platter. Fayard, Paris.

Poutrin, Isabelle (1995) Le voile et la plume: autobiographie et sainteté féminine dans l'Espagne moderne. Casa de Velázquez, Madrid.

Quinsey, Katherine M. (2012) Under the Veil: Feminism and Spirituality in Post-Reformation England and Europe. Cambridge Scholars Publishing, Cambridge.

Roccetti, Antonella. (1999) Antropologia teresiana: acercamiento humano a Teresa de Avila. Tesis Doctoral. Universidad de Oviedo, Oviedo.

Rodríguez de la Flor, Fernando (2005) Pasiones frías: secreto y disimulación en el barroco hispano. Marcial Pons, Madrid.
Roullet, Antoine (2013) "Le savoir contemplatif: les religieuses et les limites de la connaissance (Espagne, XVIe siècle)". Revue Historique, 665: 119-143.

Roullet, Antoine (2015) Corps et pénitence, les carmélites déchaussées espagnoles, 1580-1640. Casa de Velázquez, Madrid.

Rubio, Diego (2016) "Di/simulación y fronteras religiosas en la temprana modernidad". In Identidades y fronteras culturales en el mundo ibérico en la Edad Moderna, edited by Betrán, J. L.; Hernández, B. and Moreno, D. Universitat Autònoma de Barcelona, Barcelona: 39-49.

San Bartolomé, Ana de (1998) "Formación de novicias y ejercicios de piedad", in Obras completas. Monte Carmelo, Burgos.

San José, Feliciana de (1654) "Instrucción de religiosas con título de recreación espiritual". In Miguel Bautista de Lanuza, Vida de la venerable Madre Feliciana de San Joseph, carmelita descalça y priora del convento de S. Joseph de Zaragoza. D. La Puyada, Saragosse.

San José, María (1978) Instrucción de novicias (1602). Teresianum, Roma.

Sánchez Lora, José Luis (1988) Mujeres, conventos y formas de la religiosidad barroca. Fundación Universitaria Española, Madrid.

Sánchez, Francisco J. and Lewis, Tom (1999) Culture and the State in Spain, 1550-1850. Taylor and Francis, New York and London.

Santa María, Francisco de (1644-1655) Reforma de los Descalzos de Nuestra Señora del Carmen. Diego Diaz de la Carrera, Madrid.

Schlau, Stacey and Arenal, Electa (2006) «"Leyendo o y escribiendo ella": the Convent as Intellectual Community». Letras femeninas, 32, 1: 129-147.

Sluhovsky, Moshe (2007) Believe not Every Spirit: Possession, Mysticism, \& Discernment in Early Modern Catholicism. University of Chicago Press, Chicago.

Sluzki, Carlos E. and Verón, Eliseo (1971) "The Double Bind as a Universal Pathogenic Situation". Family Process, 10, 4: 397410 .

Soto, Domingo de (1962) «"Tratado del amor de Dios" (1555)». In Tratados espirituales. Biblioteca de Autores Cristianos, Madrid.

Spadaccini, Nicholas and Castillo, David R. (1994) "Models of Subjectivity in Early Modern Spain". Journal of Interdisciplinary Literary Studies, 6: 185-204.

Stallaert, Christine (1998) Ethnogenesis y ethnicidad: una aproximación histórico-anthropologica al casticismo. Proyecto A Ediciones, Barcelona.

Taylor, Charles (1989) Sources of the Self: The Making of the Modern Identity. Harvard University Press, Cambridge, MA.

Teresa de Jesús (1997) Obras completas de Santa Teresa de Jesús. Biblioteca de Autores Cristianos, Madrid.

Unamuno, Miguel de (1996) En torno al casticismo (1895). Biblioteca Nueva, Madrid

Venegas, Alejo de (2001) Agonía del tránsito de la muerte. L'Harmattan, Paris

Vidal, Fernando (2006) Les sciences de l'âme, XVIe-XVIIe siècles. Honoré Vidal, Paris

Weber, Alison (1990) Teresa of Avila and the rhetoric of femininity. Princeton University Press, Princeton.

Zarri, Gabriella (editor) (1991) Finzione e santità tra medioevo ed età moderna. Rosenberg \& Sellier, Torino. 